\title{
The Review of Macroeconomic Factors and Stock Returns
}

\author{
Nopphon Tangjitprom ${ }^{1}$ \\ ${ }^{1}$ Martin de Tours School of Management and Economics, Assumption University, Bangkok, Thailand \\ Correspondence: Nopphon Tangjitprom, Martin de Tours School of Management and Economics, Assumption \\ University, Bangkok, Thailand. Tel: 66-85-815-6177. E-mail: tnopphon@gmail.com
}

Received: March 21, 2012

Accepted: May 4, 2012 Online Published: July 5, 2012

doi:10.5539/ibr.v5n8p107

URL: http://dx.doi.org/10.5539/ibr.v5n8p107

\begin{abstract}
This paper aims to review a number of studies on macroeconomic factors and stock returns. All of the macroeconomic variables are classified into four groups: variables reflecting general economic conditions, variables related to interest rate and monetary policy, variables concerning price level, and variables concerning international activities. Furthermore, various studies on macroeconomics factors and stock returns have employed different methodologies based on their purposes and interpretations. Although the results are mixed, most studies have shown evidence that there are significant relationships between macroeconomic variables and stock returns.
\end{abstract}

Keywords: macroeconomic factors, stock returns, multi-factor model

\section{Introduction}

Studies on the factors that affect stock returns represent one popular area of financial research. Among the various factors, macroeconomic factors are widely used in those studies. This paper aims to review researches that examine the relationship between macroeconomic variables and stock returns in terms of the variables and methodology used in those studies.

The macroeconomic variables used in each study are different based on the purpose of those studies. Those macroeconomic variables can be classified into four groups. The first group reflects general economic conditions such as employment level and the industrial production index. The second group includes variables concerning interest rate and monetary policy. Those variables include interest rate, term spread, default spread, etc. The third group of variables focuses on price level, which can be general price level and inflation rate or the price of key assets such as oil prices. The last group is the variables involving international activities such as exchange rate and foreign direct investment. Some studies examine macroeconomic factors in general and include many macroeconomic variables, whereas some studies have focused on specific variables or groups of variables.

The methodology in these studies varies based on their purpose of the study. Some studies use the multiple regression technique, while some papers use more advanced models, such as the like Vector Autoregression (VAR) technique or the co-integration technique. These techniques can be interpreted in broader ways, for example, in terms of the lead-lag relationship or long-term perspective. Some studies shift their focuses to the volatility clustering concept and use the GARCH model or GARCH-family models to capture the time-varying volatility of stock returns. However, some studies focus on the announcement effect of macroeconomic news such as with monetary announcement. These studies have used the event-study approach instead of general time-series data.

The paper is organized into 4 sections, including this introduction section. Section 2 presents a review of the macroeconomic variables used in studies about macroeconomic factors, and section 3 explains the various methodologies used in those studies. Finally, section 4 will be the concluding remarks that will summarize the main ideas of the paper.

\section{Macroeconomic Variables}

In order to examine the relationship between macroeconomic variables and stock returns, some studies use various macroeconomic variables to examine which factors have the critical impacts to stock returns. Chen, Ross, and Roll (1986) have used empirical evidence to extend other risk factors besides the notion of equity market risk premium introduced in the Capital Asset Pricing Model or CAPM (Sharpe, 1964; Lintner, 1965; Mossin, 
1966). They used various macroeconomic shocks, including the industrial production index, inflation, risk premium or default spread, and term structure as additional factors in the market model as in CAPM. They found that these macroeconomic factors can significantly explain stock returns and that these factors are useful in asset pricing.

However, some studies have focused on specific areas of macroeconomic variables. The most popular area is monetary policy. Patelis (1997) for example examined the role of monetary policy in predicting stock returns. The variables in this study, including the Federal fund rate and default spread, can significantly predict stock returns in both a short-horizon and long-horizon analysis.

All of the macroeconomic variables used in these studies will be classified into four groups, which are variables reflecting general economic conditions, variables related to interest rate and monetary policy, variables concerning price level, and variables related to international activities.

\subsection{Economics Conditions}

The variables in this group capture general economic conditions and can be used as a proxy for cyclical factors. The direct measurement for economic condition is the growth rate of gross domestic products or national output. This economic growth reflects the change in real economic activities and also reflects the people's income level. Hess (2003) documents the co-integration between stock price and macroeconomic factors, including the gross domestic products in the Swiss stock market. Moreover, the variance decomposition in his study revealed the importance of the gross domestic products variable in explaining stock prices, especially regarding the cyclical sectors such as electricity, utilities, and metallurgy.

Many studies use the industrial production index as a proxy for economic conditions. The growth of production index will be consistent with the average growth of firms' sales and cash flows. Therefore, the industrial production index should be useful in the asset pricing model (Chen, Ross, \& Roll, 1986). Humpe and Macmillan (2009) used a co-integration analysis and found that there is a positive relationship between the industrial production index and stock prices in both the US and Japanese market.

Another variable used as a proxy for economic conditions is employment rate. Sing, Mehta, and Varsha (2011) examine the relationship between macroeconomic variables and stock returns in Taiwan. They found that employment rate was insignificant, whereas gross domestic product was significant. In general time-series studies, employment rate is not popular compared to the industrial production index. The industrial production index can be a better proxy for economic conditions in general. However, in specific areas such as the real estate sector, the industrial production index is not a good candidate for the cyclical factor; in that case, employment level will be used instead (Brooks \& Tsolacos, 1999).

Gross domestic savings are another variable related to economic conditions. Total saving amounts can contribute to the future growth of gross domestic products or national outputs. Pal and Mittal (2011) have studied the macroeconomic factors in the Indian capital markets and have included gross domestic savings as one of the macroeconomic variables. However, the result reveals that this variable has insignificant impacts on stock returns.

In event studies concerning macroeconomic news announcements, the announcement about employment level has a significant impact on stock returns rather than the industrial production index or gross domestic product. Boyd, Jagannathan, and Hu (2005) have studied the effect of unemployment announcements on stock prices. They found that the announcement of rising unemployment can significantly affect the stock market. Flannery and Protopapadakis (2002) found that employment announcements can affect the conditional volatility of the stock market, whereas the announcement of gross national product and industrial production are insignificant.

\subsection{Interest Rate and Monetary Policy}

The variables in this group are related to interest rate and monetary policy. Studies on interest rate and stock returns were populated in financial research before the popularity of the macroeconomic model. Stone (1974) proposes a two-index model as an extension of the single-index market model by adding interest rate measured by returns from the debt market. Thereafter, this model was very popular for measuring the returns of financial institutions like commercial banks. Lynge and Zumwalt (1980) provided evidence to support Stone's two-index model by showing that commercial banks stock returns can be explained by interest rate. However, more recent research using volatility clustering, such as EGARCH, shows contradicting results, as interest rate cannot significantly explain commercial bank stock returns (Joseph \& Vezos, 2006). Park and Choi (2011) show that in addition to commercial bank stock returns, insurer stock returns are also significantly affected by interest rate.

In general, studies about interest rate will use yields on government securities as the proxy of interest rate level. 
However, some studies focusing on monetary policy will use the central bank's key policy rate instead. Prather and Bertin (1999) have studied stock returns predictability regarding the Federal Reserve announcement of discount rate change. They show evidence that the information about discount rate change can predict stock returns movement. Li, Iscan, and Xu (2010) use the US’s Federal fund rate and Canada's overnight rate, which are key policy rates, to study the effect of policy shock on stock prices. Stock returns are affected by monetary policy shocks in both countries, whereas the effect in the US is more pronounced than in Canada. They have addressed this difference in relation to the level of stock market openness. Durham (2003) uses the discount rate from 16 countries to study the effect of monetary policy on stock returns; however, the evidence shows that the relationship between monetary policy and stock returns is weak and insignificant. Chang et al. (2011) conducted a study about monetary policy and stock returns using the Federal fund rate. They found that the Federal fund rate had little effect on stock returns but the effect was more pronounced for returns on the REIT. Some studies have used other interest rates, such as LIBOR or LIBOR futures, to be the proxy of change in interest rate level. Gregoriou et al. (2009) used 3-month Sterling LIBOR futures as the proxy for monetary policy shocks in the UK market. They found a negative relationship between interest rate changes and stock returns before the credit crisis period; however, the relationship reversed to a positive one during the credit crisis.

Some studies concerning monetary policy use the level of money supplies. Chen (2007) for example used money supply (M2) growth rate and change in the Federal fund rate to study how monetary policy variables affect stock return. Chancharat, Valadkhani, and Havie (2007) used money supplies (M2) to study the impact of macroeconomic factors on stock returns in Thailand. The result from their GARCH-M model reveals that money supplies have no impact on stock returns.

Other variables related to interest rate are term spread and default spread. Term spread, which represents the term structure variable in many researches, is the difference between the yields on long-term and short-term government securities. Chen, Ross, and Roll (1986) have suggested that this variable is the measurement of unanticipated returns on long-term bonds. Czaja and Scholz (2007) used the term structure model to examine the relationship between interest rate change and stock returns. They summarized that the negative effect of the slope of term structure or term spread on stock returns varies among industries. The automobile and utilities industries, which are industries that depend on large initial capital investment and long-term financing, are more sensitive to the term spread.

The default spread is the difference between yields on risky corporate bonds and yields on government bonds. Chen, Ross, and Roll (1986) have measured this default spread according to the difference between yields on low-grade bonds and government bonds. This variable measures the risk aversion level. They also show evidence of a positive relationship between this default spread (risk premium) and stock returns.

\subsection{Price Level}

This group of variables involves price level. In general, the consumer price index is the most popular measurement of general price level and inflation. Chen, Ross, and Roll (1986) measured this inflation level according to two separate variables. The first variable was unexpected inflation, which is the difference between actual inflation and expected inflation rate. The actual inflation rate is derived from the percentage change in the consumer price index. The other variable is the change in expected inflation. This change in expected inflation reflects the inflation forecasting from other economic factors. These authors also document a negative relationship between both inflation variables and stock returns. Adrangi, Chatrath, and Raffiee (1999) found that both unexpected inflation and expected inflation had a negative relationship with stock returns in Korea. Kutan and Aksoy (2003) have studied the effect of inflation stock returns in Turkey. They used not only contemporaneous but also the lagged inflation rate in their EGARCH model and found that there was a positive total effect of inflation on stock returns. However, inflation changes at a higher rate than average stock returns. Kolluri and Wahab (2008) use an asymmetric model to examine the relationship between expected inflation and stock returns. They found that a negative relationship exists during low inflation regimes whereas there is a positive relationship during high inflation regimes.

Some studies have focused on oil prices, which is a critical asset in both the production and consumption process. It is also a proxy for cost-push inflation. Faff and Brailsford (1999) have shown evidence for Australian equity return sensitivities in relation to oil price changes. These sensitivities vary across industries, such as with the negative effects of the oil and gas industry but negative effects regarding the paper, packaging and transportation industries. Kilian and Park (2009) have studied the effect of oil price shock on stock returns by separating oil price shocks into demand shocks and supply shocks. They found that only oil demand shocks have a significant impact on stock returns. Fedorova and Pankratov (2010) used Brent oil price to examine the influence of 
macroeconomic factors on stock returns in Russia. The results reveal that the Brent oil prices are the macroeconomic factor that most affects stock returns. In recent years, gold has become an interesting alternative investment for investors around the world. Some recent studies on macroeconomic factors have included gold as one of the macroeconomic variables. For example, Buyuksalvarci (2010) has included gold prices as another macroeconomic variable in examining their impact on stock returns in Turkey. However, the results reveal that the effect of gold prices is insignificant, whereas other macroeconomic variables are significant.

\subsection{International Activities}

Globalization makes international activities become more important. Exchange rate is one of the most important factors in this group, especially for the countries that depend to a great extent on international trading activities. Maysami, Howe, and Hamzah (2004) have studied the relationship between stock returns and macroeconomic variables, including exchange rate in Singapore. They found a significantly positive relationship, which can intuitively be explained by the high level of international trade of Singapore.

In other studies, other variables, such as foreign direct investment or foreign exchange reserves, have been included. Adam and Tweneboah (2008) have examined the effects of macroeconomic factors on stock price movement in Ghana. They included foreign direct investment and exchange rate in the macroeconomic factors. They found the importance of foreign direct investment regarding stock price movement during short periods. However, in the long period, interest rate and inflation rate play more significant roles. Mohammed et al. (2009) used foreign exchange reserve and foreign exchange rate together with other macroeconomic variables to study stock returns in Pakistan. They found that both foreign exchange reserve and foreign exchange rate were more significant compared to other macroeconomic variables.

\section{Review of Methodology}

\subsection{Regression Models}

The multiple regression technique is one of the most popular techniques in econometrics. The regression analysis can be used to examine the relationships among variables. The multiple regression models are as follows.

$$
y_{i}=\alpha+\sum_{j=1}^{m} \beta_{j} x_{j i}+\varepsilon_{i}
$$

where $y_{i}$ is stock returns and $x_{i}$ represents $j$ number of macroeconomic factors used in the study. This multiple regression technique can be simply interpreted concerning whether a set of macroeconomic variables has a relationship with stock returns.

However, the capital asset pricing model (Sharpe, 1964; Lintner, 1965; Mossin, 1966) suggests that stocks should be priced by systematic risk or Beta measured by the movement between stock returns and market portfolio returns. This implies that stock returns can be solely explained by a single factor, which is the market equity risk premium. However, many scholars have proposed an extension of this and this becomes the multi-factor model, as follows:

$$
R_{i}=\alpha+\beta_{1} R M_{i}+\sum_{j=1}^{m} \beta_{j+1} F_{j i}+\varepsilon_{i}
$$

where $R_{i}$ is excess return on stocks, which is the difference between stock returns and risk-free rate. $R M_{i}$ is the market factor measured by the market equity risk premium. $F_{i}$ are other factors having an impact on stock return in addition to the market factor.

One of the notable multi-factor models is the model proposed by Chen, Ross, and Roll (1986) which shows empirical evidence for the Arbitrage Pricing Theory (Ross, 1976; Roll \& Ross, 1980). In their model, other factors used in the study are macroeconomic factors, including the industrial production index, term spread, default spread, expected inflation, and unexpected inflation. These macroeconomic factors have become the mainstream of later studies on macroeconomic and stock returns.

Another possible method as an extension of the regression model is quantile regression. In normal regression, the relationship is examined based on the mean value, whereas quantile regression examines the median and other quantiles instead. Chen, Wang, and Cheng (2009) used the quantile regression technique to examine the relationship of stock prices and exchange rate. They found a negative impact of exchange rate on stock returns in most of quantiles; however, the impact of stock returns on exchange rate was insignificant at most quantiles.

\subsection{Volatility Clustering and the GARCH-family Model}

Stock markets are characterized by time-varying volatility, which is formally captured by Autoregressive Conditional Heteroskedastics or the ARCH model (Engle, 1982). After its introduction, this time-varying 
volatility model became popular in financial research. Bollerslev (1986) proposed for example a general form of the ARCH model in which the explanation of conditional variance can be captured parsimoniously. This model is known as Generalized Autoregressive Conditional Heteroskedastics or the GARCH model. In econometrics, the GARCH model is used as a variance equation to be estimated simultaneously with the normal regression model in the mean equation. This technique eliminates conditional heteroskedastics problems and makes the interpretation of the results in the mean equation become more valid. The GARCH specification is as follows.

$$
\begin{aligned}
& y_{i}=\alpha+\sum_{j=1}^{m} \beta_{j} x_{j i}+\varepsilon_{i} \\
& h_{t}=\omega+\alpha \varepsilon_{t-1}^{2}+\beta h_{t-1}+v_{t}
\end{aligned}
$$

where $h_{t}$ is the conditional variance of the residual from mean equation. $\varepsilon_{t-1}^{2}$ represents ARCH term, and $h_{t-1}$ represents the GARCH term. The coefficient of the ARCH term can be interpreted as short-term volatility persistence, whereas the coefficient of the GARCH term is interpreted as long-term volatility persistence.

Some studies use an extension of the GARCH model, which is known as GARCH-M or GARCH-in-Mean as follows.

$$
\begin{aligned}
& y_{i}=\alpha+\sum_{j=1}^{m} \beta_{j} x_{j i}+\gamma \sqrt{h_{t}}+\varepsilon_{i} \\
& h_{t}=\omega+\alpha \varepsilon_{t-1}^{2}+\beta h_{t-1}+v_{t},
\end{aligned}
$$

where $h_{t}$ is the conditional volatility term in the mean equation. Theconditional volatility is included in the mean equation in order to capture the risk premium, which should be priced by rational investors (Engle, Lilien, \& Robins, 1987). Chancharat, Valadkhani, and Havie (2007) used the GARCH-M model to study macroeconomic factors in relation to stock returns in Thailand and found evidence of volatility clustering as represented in the GARCH-M model.

However, the effect of time-varying volatility may not be symmetric. For example, the high volatility may be more persistent during a bear market than a bull market. Nelson (1991) proposed Exponential GARCH or the EGARCH model, which allows asymmetric responses of conditional variance. The EGARCH specification is as follows.

$$
\begin{aligned}
& y_{i}=\alpha+\sum_{j=1}^{m} \beta_{j} x_{j i}+\varepsilon_{i} \\
& \ln h_{t}=\omega+\alpha\left|\frac{\varepsilon_{t-1}}{\sqrt{h_{t-1}}}\right|+\gamma \frac{\varepsilon_{t-1}}{\sqrt{h_{t-1}}}+\beta \ln h_{t-1}+v_{t}
\end{aligned}
$$

where $\alpha$ and $\gamma$ are used to capture the asymmetric effect in the conditional variance. Kutan and Aksoy (2003) have used EGARCH in their study of the inflation effect on stock returns in Turkey and found that there was a positive total effect of inflation on stock returns.

\subsection{Dynamic Model and Long-term Relationships}

Some studies have used Vector Autoregression or the VAR model, which is a multivariate model of the well-know univariate time-series model, Autoregression or AR model. The VAR model as made popular by Sim (1980). The specification of this model is as follows.

$$
Y_{t}=C+\sum_{j=1}^{m} A_{j} Y_{t-j}+v_{t}
$$

where $Y_{t}$ represents the vector of all variables with the dimension of $\mathrm{n}$ by 1 , where $\mathrm{n}$ is the number of variables used in the study. $Y_{t-j}$ is the vectors of the j-th lag variables with dimension $\mathrm{n}$ by 1 . C is the vector of constant term. $A_{j}$ is the coefficient matrix for the lag variables vector with the dimension of $\mathrm{n}$ by $\mathrm{n}$. If we simplify the above VAR specification for 2 lags and 2 variables, the system of equations for VAR (2) with two variables is as follows.

$$
\begin{aligned}
& y_{t}=\alpha_{1}+\beta_{11} y_{t-1}+\beta_{12} x_{t-1}+v_{1} \\
& x_{t}=\alpha_{2}+\beta_{21} y_{t-1}+\beta_{22} x_{t-1}+v_{2}
\end{aligned}
$$

There are numerous advantages of using the VAR model over multiple regression models. The VAR model, for example, is a dynamic model, whereas the normal multiple regression model is a static model and can capture only the contemporaneous relationships among variables. However, the VAR model can examine the lead-lag 
relationships among the variables in the model. The most popular method is known as the Granger Causality Test proposed by Granger (1969). This test can help to make conclusions about the predictability of whether macroeconomic variables can be used to predict future stock price movement or whether stock returns can be used to predict future macroeconomic conditions. Asai and Shiba (1995) have shown evidence that macroeconomic variables have Granger-caused stock returns but they found no evidence that stock returns Granger-caused macroeconomic variables in Japan. Hondroyiannis and Papapetrou (2001) have also documented a similar direction of the relationships for the stock market in Greece. However, Tangjitprom (2012) found the opposite result, as stock returns Granger-cause most macroeconomic variables in Thailand.

Furthermore, the VAR model can be extended to further analysis, such as variance decomposition and the impulse response function. Variance decomposition decomposes the variation of stock returns sensitive to each macroeconomic variable in the model. The impulse response function can be used to show how stock returns are sensitive to the change in each macroeconomic variable. Patelis (1997) used the variance decomposition technique to examine the effect of monetary policy on excess returns on stocks. Li, Iscan, and Xu (2010) used both variance decomposition and the impulse response function to examine the monetary policy shocks in relation to stock returns in US and Canada.

Some studies have employed co-integration techniques to examine the relationship between stock returns and macroeconomic variables. Co-integrated variables have shown a common stochastic trend, which can be used to represent a long-term relationship. Engle and Granger (1987) have formulated the co-integration concept and proposed the formal test of co-integration, which is known as the Engle and Granger two-step method. Engle and Granger's co-integration test can be used to examine the co-integrations among two or more variables. However, in case of more than two variables, it is possible that there will be more than one co-integration vector. Johansen and Juselius (1990) have proposed a testing procedure that can capture the existence of more than one co-integration vector. The result of Johansen and Juselius's work can capture the number of co-integration vectors among variables.

In most studies concerning the dynamic and long-term relationship between stock returns and macroeconomic variables, the Vector Autoregression and co-integration methods are employed together. If there no co-integration vectors exist among variables, the normal Vector Autoregression or VAR model will be used. However, if there is one or more co-integration vectors, the Vector Error Correction Model (VECM) will be employed instead of the normal VAR model. For example, Hess (2003) found evidence of co-integration vectors among stock returns and macroeconomic variables in Switzerland and employed the VECM to analyze the effect of macroeconomic variables on stock markets using variance decomposition.

\subsection{Event Studies}

Unlike general time-series data analysis, event studies have focused on the change surrounding specific events. The effect of specific events will be included in stock price changes immediately and should be measured around those events (Brown \& Warner, 1980; Mackinlay, 1997). The event-study methodology has become popular in financial researches since the study of Fama, Fisher, Jensen, and Roll (1969). In this context, event studies will be used to examine the effects to stock returns during the event of macroeconomic news. The most popular macroeconomic event is the announcement of monetary policy by the Central Bank. Prather and Bertin (1999) have studied the stock return movement surrounding the Fed announcement of discount rate changes.

Other popular studies concerning macroeconomic news announcements are announcements about employment level. Flannery and Protopapadakis (2002) found that announcements about employment level can significantly affect stock market volatility, whereas the announcements of other variables such as gross national products or industrial productions are insignificant. Boyd, Jagannathan, and Hu (2005) found that the announcement of rising unemployment can significantly affect the stock market.

Some studies on macroeconomic factors use the event studies method by measuring the impact on stock returns surrounding macroeconomic news announcements by separating local and global news. For example, Buttner, Hayo, and Neuenkirch (2012) studied the effect of macroeconomic news on the stock market markets in Czech, Hungary, and Poland and found that news about European countries has a greater impact than news from the US.

\section{Concluding Remarks}

According to numerous studies on the macroeconomic factors and stock returns, the results are mixed and they cannot be directly comparable. This is because different studies have employed different methodologies and can be interpreted in different ways. Nevertheless, most studies show evidence to support the notion that there is a relationship between stock returns and macroeconomic variables from both short-term and long-term 
perspectives. However, this interpretation needs to be made with caution, as most of studies have shown that only little variation in stock returns can be explained by those macroeconomic variables.

Another issue in the interpretation of this relationship is whether it is a contemporaneous or lead-lag relationship. Many studies on the factors that affect stock returns would like to examine stock return predictability. In other words, the change in macroeconomic variables can be used to explain future stock returns. However, the existing results of this implication are mix. Many studies have shown that macroeconomic variables can be used to explain future stock returns (Asai \& Shiba, 1995; Hondroyiannis \& Papapetrou, 2001). However, some studies have shown the reverse of this relationship, as stock returns can be use to predict future macroeconomic variables (Tangjitprom, 2012). One example of this relationship is from the study of Henry, Olekalns, and Thong (2004), who have employed a non-linear model to show evidence from 27 countries that stock returns are useful in predicting output growth.

\section{References}

Adam, A. M., \& Tweneboah, G. (2008). Macroeconomic Factors and Stock Market Movement: Evidence from Ghana. MRPA Working Paper 11256.

Adrangi, B., Chatrath, A., \& Raffiee, K. (1999). Inflation, Output, and Stock Prices: Evidence from Two Major Emerging Markets. Journal of Economics and Finance, 23(3), 266-278. http://dx.doi.org/10.1007/BF02757711

Asai, M., \& Shiba, T. (1995). The Japanese Stock Market and the Macroeconomy: An Empirical Investigation. Financial Engineering and the Japanese Markets, 2, 259-267. http://dx.doi.org/10.1007/BF02425199

Bollerslev, T. (1986). Generalized Autoregressive Conditional Heteroskedasticity. Journal of Econometrics, 31, 307-327. http://dx.doi.org/10.1016/0304-4076(86)90063-1

Boyd, J. H., Hu, J., \& Jagannathan, R. (2005). The Stock Market's Reaction to Unemployment News: Why Bad News Is Usually Good for Stocks. The Journal of Finance, 60(2), 649-672. http://dx.doi.org/10.1111/j.1540-6261.2005.00742.x

Brooks, C., \& Tsolacos, S. (1999). The impact of economic and financial factors on UK property performance. Journal of Property Research, 16(2), 139-152. http://dx.doi.org/10.1080/095999199368193

Brown, S. J., \& Warner, J. B. (1980). Measuring Security Price Performance. Journal of Financial Economics, 8(3), 205-258. http://dx.doi.org/10.1016/0304-405X(80)90002-1

Buttner, D., Hayo, B., \& Neuenkirch, M. (2012). The impact of foreign macroeconomic news on financial markets in the Czech Republic, Hungary, and Poland. Empirica, 39(1), 19-44. http://dx.doi.org/10.1007/s10663-010-9153-0

Buyuksalvarci, A. (2010). The Effects of Macroeconomics Variables on Stock Returns: Evidence from Turkey. European Journal of Social Sciences, 14(3), 404-416.

Chancharat, S., Valadkhani, A., \& Havie, C. (2007). The Influence of International Stock Markets and Macroeconomics Variables on The Thai Stock Market. Applied Econometrics and International Development, 7(1), 221-238.

Chang, K.-L., Chen, N.-K., \& Leung, C. K. Y. (2011). Monetary Policy, Term Structure and Asset Return: Comparing REIT, Housing and Stock. The Journal of Real Estate Finance and Economics, 43(1), 221-257. http://dx.doi.org/10.1007/s11146-010-9241-8

Chen, J.-b., Wang, D.-l., \& Cheng, T.-t. (2009). Empirical Study of Relations between Stock Returns and Exchange Rate Fluctuations in China. Cutting-Edge Research Topics on Multiple Criteria Decision Making, 35, 447-454. http://dx.doi.org/10.1007/978-3-642-02298-2_66

Chen, N.-F., Roll, R., \& Ross, S. (1986). Economic Forces and the Stock Market. The Journal of Business, 59(3), 383-403. http://dx.doi.org/10.1086/296344

Chen, S.-S. (2007). Does Monetary Policy Have Asymmetric Effects on Stock Returns? Journal of Money, Credit and Banking, 39(2-3), 667-688. http://dx.doi.org/10.1111/j.0022-2879.2007.00040.x

Czaja, M.-G., \& Scholz, H. (2007). Sensitivity of Stock Returns to Changes in the Term Structure of Interest Rates - Evidence from the German Market. Operation Research Proceedings, 2006, 305-310.

Durham, J. B. (2003). Monetary Policy and Stock Price Returns. Financial Analysts Journal, 59(4), 26-35. http://dx.doi.org/10.2469/faj.v59.n4.2543 
Engle, R. (1982). Autoregressive Conditional Heteroskedasticity with Estimates of the Variance of U.K. Inflation. Econometrica, 50(4), 987-1008. http://dx.doi.org/10.2307/1912773

Engle, R. F., \& Granger, C. (1987). Co-integration and error correction: Representation, estimation and testing. Econometrica, 55(2), 251-276. http://dx.doi.org/10.2307/1913236

Engle, R. F., Lilien, D. M., \& Robins, R. P. (1987). Estimating Time Varying Risk Premia in the Term Structure: The Arch-M Model. Econometrica, 55(2), 391-407. http://dx.doi.org/10.2307/1913242

Faff, R. W., \& Brailsford, T. J. (1999). Oil price risk and the Australian stock market. Journal of Energy Finance and Development, 4, 69-87. http://dx.doi.org/10.1016/S1085-7443(99)00005-8

Fama, E. F., Fisher, L., Jensen, M. C., \& Roll, R. (1969). The Adjustment of Stock Price to New Information. International Economic Review, 10(1), 1-21. http://dx.doi.org/10.2307/2525569

Fedorova, E. A., \& Pankratov, K. A. (2010). Influence of Macroeconomic Factors on the Russian Stock Market. Studies on Russian Economic Development, 21(2), 165-168. http://dx.doi.org/10.1134/S1075700710020061

Flannery, M. J., \& Protopappadakis, A. A. (2002). Macroeconomics Factors Do Influence Aggregate Stock Returns. The Review of Financial Studies, 15(3), 751-782. http://dx.doi.org/10.1093/rfs/15.3.751

Granger, C. (1969). Investigating causal relations by econometric models and cross-spectral methods. Econometrica, 37(3), 424-438. http://dx.doi.org/10.2307/1912791

Gregorio, A., Kontonikas, A., MacDonald, R., \& Montagnoli, A. (2009). Monetary policy shocks and stock returns: evidence from the British market. Financial Markets and Portfolio Management, 23(4), 401-410. http://dx.doi.org/10.1007/s11408-009-0113-2

Henry, O. T., Olekalns, N., \& Thong, J. (2004). Do Stock Market Returns Predict Changes to Output? Evidence from a Nonlinear Panel Data Model. Empirical Economics, 29(3), 527-540. http://dx.doi.org/10.1007/s00181-003-0182-4

Hess, M. (2003). Sector Specific Impacts of Macroeconomic Fundamentals on the Swiss Stock Market. Financial Markets and Portfolio Management, 17(2), 234-245. http://dx.doi.org/10.1007/s11408-003-0205-3

Hondroyiannis, G., \& Papapetrou, E. (2001). Macroeconomic Influences on the Stock Market. Journal of Economics and Finance, 25(1), 33-49. http://dx.doi.org/10.1007/BF02759685

Humpe, A., \& Macmillan, P. (2009). Can macroeconomic variables explain long term stock market movements? A comparison of the US and Japan. Applied Financial Economics, 19(2), 111-119. http://dx.doi.org/10.1080/09603100701748956

Johansen, S., \& Juselius, K. (1990). Maximum Likelihood Estimation and Inference on Cointegration-with Applications to the Demand for Money. Oxford Bulletin of Economics and Statistics, 52, 169-210. http://dx.doi.org/10.1111/j.1468-0084.1990.mp52002003.x

Joseph, N. L., \& Vezos, P. (2006). The sensitivity of US banks' stock returns to interest rate and exchange rate changes. Managerial Finance, 32(2), 182-199. http://dx.doi.org/10.1108/0307435061064193

Kilian, L., \& Park, C. (2009). The Impact of Oil Price Shocks on the U.S. Stock Market. International Economics Review, 50(4), 1267-1287. http://dx.doi.org/10.1111/j.1468-2354.2009.00568.x

Kolluri, B., \& Wahab, M. (2008). Stock returns and expected inflation: evidence from an asymmetric test specification. Review of Quantitative Finance and Accounting, 30(4), 371-395. http://dx.doi.org/10.1007/s11156-007-0060-9

Kutan, A. M., \& Aksoy, T. (2003). Public Information Arrival and the Fisher Effect in Emerging Markets: Evidence from Stock and Bond Markets in Turkey. Journal of Financial Services Research, 23(3), 225-239. http://dx.doi.org/10.1023/A:1024671612784

Li, Y. D., Iscan, T. B., \& Xu, K. (2010). The Impact of Monetary Policy Shocks on Stock Prices: Evidence from Canada and the United States. Journal of International Money and Finance, 29(5), 876-896. http://dx.doi.org/10.1016/j.jimonfin.2010.03.008

Lintner, J. (1965). The Valuation of Risk Assets and the Selection of Risky Investments in Stock Portfolios and Capital Budgets. Review of Economics and Statistics, 47, 13-37. http://dx.doi.org/10.2307/1924119 
Lynge, M. J., \& Zumwalt, J. K. (1980). An Empirical Study of the Interest Rate Sensitivity of Commercial Bank Returns: A Multi- Index Approach. The Journal of Financial and Quantitative Analysis, 15(3), 731-742. http://dx.doi.org/10.2307/2330406

MacKinlay, A. C. (1997). Event Studies in Economics and Finance. Journal of Economic Literature, 35, 13-39.

Maysami, R. C., Howe, L. C., \& Hamzah, M. A. (2004). Relationship between Macroeconomic Variables and Stock Market Indices: Cointegration Evidence from Stock Exchange of Singapore's All-S Sector Indices. Jurnal Pengurusan, 24, 47-77.

Mohammad, S. D., Hussain, A., Jalil, M. A., \& Ali, A. (2009). Impact of Macroeconomics Variables on Stock Prices: Emperical Evidance in Case of Kse (Karachi Stock Exchange). European Journal of Scientific Research, 38(1), 96-103.

Mossin, J. (1966). Equilibrium in a Capital Asset Market. Econometrica, 34(4), 768-783. http://dx.doi.org/10.2307/1910098

Nelson, D. B. (1991). Conditional Heteroskedasticity in Asset Returns: A New Approach. Econometrica, 59(2), 347-370. http://dx.doi.org/10.2307/2938260

Pal, K., \& Mittal, R. (2011). Impact of macroeconomic indicators on Indian capital markets. The Journal of Risk Finance, 12(2), 84-97. http://dx.doi.org/10.1108/15265941111112811

Park, J., \& Choi, B. P. (2011). Interest rate sensitivity of US property/liability insurer stock returns. Managerial Finance, 37(2), 134-150. http://dx.doi.org/10.1108/03074351111103677

Patelis, A. D. (1997). Stock Return Predictability and The Role of Monetary Policy. The Journal of Finance, 52(5), 1951-1972. http://dx.doi.org/10.2307/2329470

Prather, L., \& Bertin, W. J. (1999). Market Efficiency, Discount-Rate Changes, and Stock Returns: A Long-Term Perspective. Journal of Economics and Finance, 23(1), 56-63. http://dx.doi.org/10.1007/BF02752687

Roll, R., \& Ross, S. (1980). An empirical investigation of the arbitrage pricing theory. Journal of Finance, 35(5), 1073-1103. http://dx.doi.org/10.2307/2327087

Ross, S. (1976). The arbitrage theory of capital asset pricing. Journal of Economic Theory, 13(3), 1073. http://dx.doi.org/10.1016/0022-0531(76)90046-6

Sharpe, W. F. (1964). Capital Asset Prices: A Theory of Market Equilibrium under Donditions of Risk. Journal of Finance, 19, 425-442. http://dx.doi.org/10.2307/2977928

Sims, C. A. (1980). Macroeconomics and Reality. Econometrica, 48(1), 1-48. http://dx.doi.org/10.2307/1912017

Singh, T., Mehta, S., \& Varsha, M. S. (2011). Macroeconomic factors and stock returns: Evidence from Taiwan. Journal of Economics and International Finance, 2(4), 217-227.

Stone, B. K. (1974). Systematic Interest-Rate Risk in a Two-Index Model of Returns. The Journal of Financial and Quantitative Analysis, 9(5), 709-721. http://dx.doi.org/10.2307/2329656

Tangjitprom, N. (2012). Macroeconomic Factors of Emerging Stock Market: The Evidence from Thailand. International Journal of Financial Research, 3(2). 